\title{
Optimization of maturity age for coppice oak forests within Left-Bank Forest-Steppe in Ukraine
}

\author{
Victor Tkach ${ }^{1}$, Igor Buksha ${ }^{1}$, Oleksandr Slych ${ }^{2}$ and Volodymyr Pasternak ${ }^{1 *}$ \\ ${ }^{1}$ Ukrainian Research Institute of Forestry and Forest Melioration named after G. M. Vysotsky (URIFFM) Pushkinska 86, Kharkiv, \\ Ukraine \\ ${ }^{2}$ State Enterprise «Konotop Forestry» Konotopskykh partyzan 97, Konotop, Sumy Region, Ukraine
}

\begin{abstract}
Oak (Quercus robur L.) forest stands are among the most common forest formations in the forest-steppe zone of Ukraine. Investigations of the patterns of distribution of trees by diameter and the dynamics of the commodity structure of mature oak stands of coppice origin were carried out based on the forest survey data from 28 temporary sample plots, on the sites designated for the final felling in the Left-Bank Forest Steppe of Ukraine (Sumy, Kharkiv, and Poltava Regions). We distributed trees by diameter classes and technical suitability categories. To establish the commodity structure of the stand, we selected model trees that corresponded to the average size of trees in terms of diameter classes and their qualitative characteristics. Then, we constructed a model tree stem profile using Institute of Forest Ecosystems Research (IFER)'s method of "6 points". Based on stands' structure and quality condition as well as on the growth tables, the commodity structure dynamics table for the changes in the commodity structure for the coppice oak stands in the Left-Bank Forest Steppe of Ukraine has been developed. The results of the analysis of wood stock dynamics showed that the maximum average increment of class $A$ and B wood is $90-100$ years. Therefore, the age of technical maturity and the associated age for the final felling in commercial oak forests of second site class and above should be assigned to $91-100$ years.
\end{abstract}

Key words: oak; industrial timber; coppice stand; commodity structure; marketability dynamics

Editor: Igor Štefančík

\section{Introduction}

Pedunculate or English oak (Quercus robur L.) is widespread in Europe (Eaton et al. 2016), and its stands provide important environmental and economic services. Oak-dominated forests occupy about $28 \%$ of the total forest area and $24 \%$ of gross living stock in Ukraine (Forestry of Ukraine 2017). Other oak species: Pubescent oak (Quercus pubescens Willd.), Sessile oak (Quercus petraea (Matt.) Liebl.), Northern red oak (Quercus rubra L.) occupy a relatively small area. In the Forest-Steppe zone of Ukraine, oak forest stands are among the most common forest formations in the forest-typological area of fresh temperate climate (Ostapenko \& Tkach 2002) (Fig. 1). The forests of the Left-Bank Forest-Steppe are represented mainly by the stands of common oak, which occupy $46.4 \%$. The area of natural oak stands is more than 280 thousand hectares ( $46 \%$ of oak forests total area of the study region), the share of natural seed origin stands is only $7.0 \%$, the rest - stands of coppice origin. The largest share of oak stands of the Left Bank Forest
Steppe is concentrated in fresh fertile (74\%), fresh relatively fertile (12\%) and dry fertile (6\%) forest site conditions. English oak is a valuable deciduous species that is rather vulnerable to climate change (Shvidenko et al. 2018; Árvai, M. et al. 2018). The most valuable oak wood has narrow rings and is produced in high mixed forests on fertile sites with a long rotation period (about 130 years) (Praciak et al. 2013).

Specification of the optimal rotation period of forest growth is essential in the system of adaptive forestry activities under changing conditions for forest species growth (Climate change guidelines for forest managers 2013; Forest Europe 2020). The maturity age and the associated age of final felling is the most important elements of sustainable forest management systems (Duncker et al. 2012).

The maturity of a forest is a condition in which it is best suited to the purpose of the economy, that is, it most fully meets the needs for specific wood assortments or exhibits its useful properties. The "forest maturity" term 


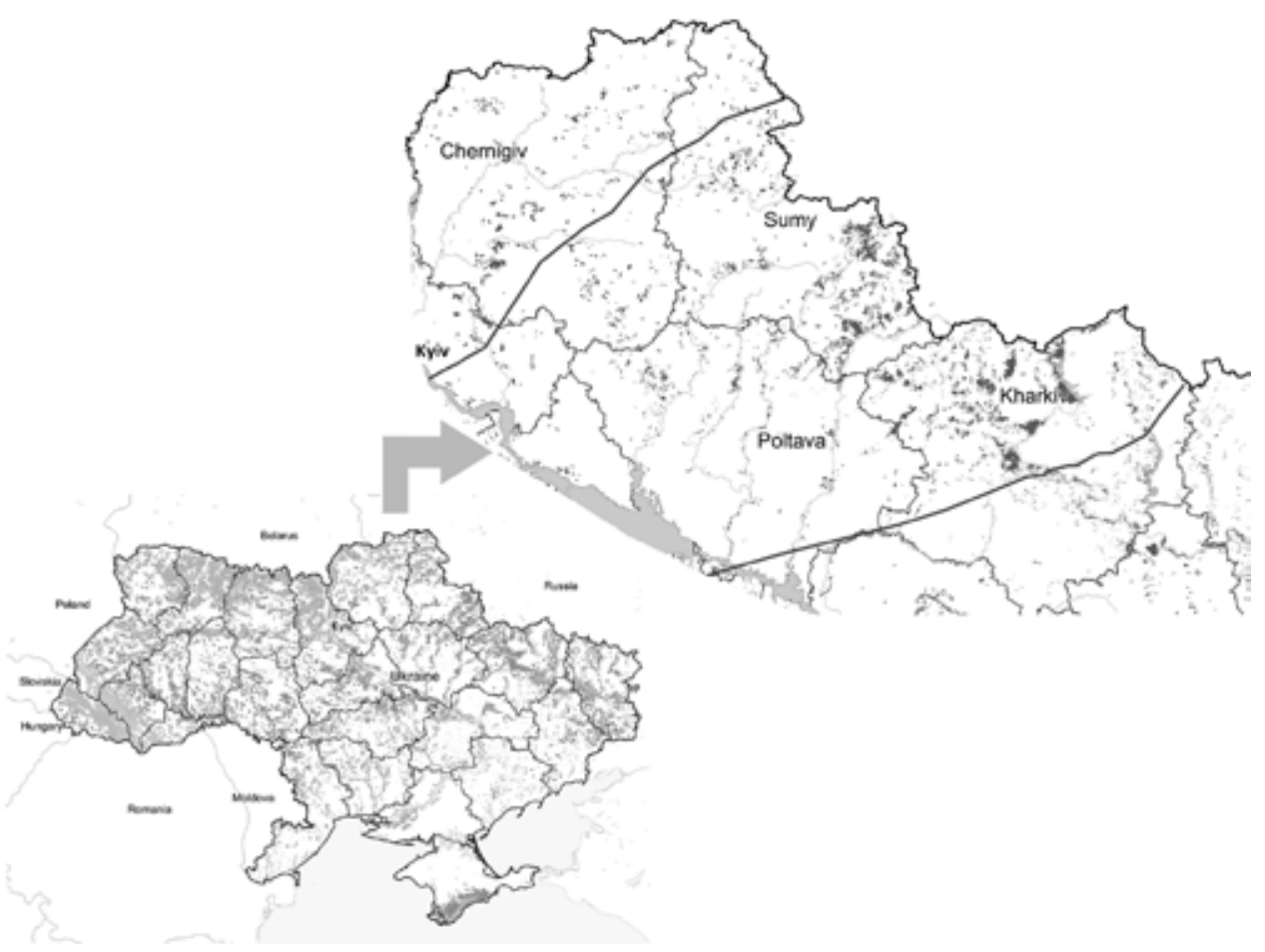

Fig. 1. Forest map of Ukraine (left) and distribution of oak forest in the region of study (right, dark gray color).

should be specified for a certain object, that is, for the stands of specific forest tree species within a natural zone or for a specific enterprise and forest area. The age of maturity of forest stands is determined based on the main purpose of the forests, the functions they perform, productivity, biological features of tree species, forest types, natural zones, as well as methods of forest regeneration.

All types of maturity can be divided into two groups, namely biological and economic. There are two phases of biological maturity in the life of the forest: restorative and natural. These types of maturity, which are limited by the biological characteristics of tree species, have been studied for the forest conditions of Ukraine (Girs 2011).

Economic maturity can also be divided into two subgroups. The first subgroup combines the types of maturity associated with the use of timber obtained during forest growing (quantitative, technical, and economic maturity); the second one includes types related to a variety of beneficial properties of the forest (water conservation and protective).

Quantitative maturity, indicating the moment at which the forest stand has the highest productivity in the growing stock, can only satisfy the one-sided requirement for the most favourable production of volumes of timber, regardless of its quality. In modern conditions, quantitative maturity can determine the age of felling only in limited areas of commercial forests where low quality and fine timber is harvested. It should be considered that there is a minimum age of stands at which the physical properties of the timber acquire the necessary parameters and the timber becomes the most suitable for wood pro- cessing (Girs 2011). Therefore, technical maturity has recently become decisive for commercial forests.

At the age of technical maturity, the maximum average increment of the leading assortment or group of major assortments is recorded. Technical maturity reflects the targeting of forest management in certain economic and natural conditions. Determining the age of technical maturity is based on the data on the stand marketability dynamics (Petráš et al. 1996), the relevance of which is also due to the introduction in Ukraine since 2019 new standards for round timber, harmonized with European ones (Hardwood round timber - Qualitative classification 2018).

The main disadvantage of the current maturity ages standards is that they are insufficiently differentiated by productivity, origin, types of forests, and almost do not consider the age structure of the forests of Ukraine. In particular, for seed-origin oak forests of site index I and above, within the commercial forests for Forest zone and Forest steppe, the maturity age by current standards is the same as for coppice oak stands of site index II (101-110 years), although the biological and growth characteristics of the latter are substantially different (Davidov 1987; Kashpor \& Strochynskyi 2013).

For coppice oak stands, the current age of maturity is too high. First, it concerns the recreational and conservation forests included in the calculation of the annual allowable cutting rate (131-140 years). In the ForestSteppe of Ukraine, at this age, the marketability of such stands and their health are deteriorating; as a result, forest stands perform important ecological and protective 
functions less effectively. The same maturity age for oak stands of different origins is not justified (Tkach et al. 2002). Silvicultural Guidelines for European Coppice Forest (Nicolescu et al. 2017) propose a short rotation period of 35-40 years for oak stands.

The aim of the study is to estimate commodity structure dynamics and substantiate the optimal maturity age for oak coppice forests of Left-Bank Forest-Steppe of Ukraine.

\section{Material and methods}

To analyse indicators of the forest fund and to develop marketability tables, we used the "Forest Fund of Ukraine" database as at 2014 and data of 28 temporary sample plots (measurements were performed on 2011-2018 years) in Sumy (State Enterprises "Lebedyn Forestry" and "Konotop Forestry"), Kharkiv (State Enterprise "Gutianske Forestry") and Poltava (State Enterprise "Gadiatske Forestry") Regions in the Left-Bank Forest-Steppe (Table 1). On the sample plots we investigated the patterns of distribution of trees by diameter and the dynamics of the commodity structure of mature oak stands of coppice origin.

Table 1. Distribution of sample plots by forest site condition and site indexes.

\begin{tabular}{lccccccc}
\hline \multirow{2}{*}{ Site index } & \multicolumn{7}{c}{ Forest site condition } \\
\cline { 2 - 7 } & $\mathrm{B}_{2}$ & $\mathrm{~B}_{3}$ & $\mathrm{C}_{2}$ & $\mathrm{C}_{3}$ & $\mathrm{D}_{2}$ & $\mathrm{D}_{3}$ & \\
\hline I & - & - & - & - & 1 & - & 1 \\
II & - & - & 9 & 2 & 12 & 1 & 24 \\
III & 1 & 1 & 1 & - & - & - & 3 \\
Total & 1 & 1 & 10 & 2 & 13 & 1 & 28 \\
\hline
\end{tabular}

In the Ukrainian forest type classification scheme, there are four classes of forest site condition distinguished by soil fertility, which is considered as soil richness in nutrients. These classes are the following: poor (A), relatively poor (B), relatively fertile (C) and fertile (D). The second variable for forest site condition type differentiation is soil moisture. Six classes are distinguished by this parameter. These classes are the following: 0 - very dry, 1 - dry, 2 - moist, 3 - damp, 4 - wet, 5 - swampy (arranged according to raise of water availability). A combination of soil fertility and soil moisture classes forms a forest site condition class, which is indicated by two characters e.g. $\mathrm{A}_{1}$ or $\mathrm{D}_{2}$. Thus, a forest site condition type class is considered as a set of conditions, which can support certain type of forest vegetation that is characterized by particular productivity, composition and structure (Bondar et al. 2020).

By types of forest site conditions, the largest share is occupied by $\mathrm{D}_{2}(46.4 \%)$ and $\mathrm{C}_{2}(35.7 \%)$, and by productivity - site index II (85.7\%). The sample plots cover forest stands between 76 and 139 years old, with an average diameter of $28.2-55.8 \mathrm{~cm}$ and an average height of $19.1-29.2 \mathrm{~m}$.

On the sample plots, we distributed trees by diameter classes and technical suitability categories. To establish the commodity structure of the stand, we selected model trees that corresponded to the average size of trees in terms of diameter classes and their qualitative characteristics. Then, we constructed model tree stem profile using IFER's method of "6 points". For this purpose, heights of stems and diameters at the stumps, heights of 1.3 and $2 \mathrm{~m}$, half of the height of the crown and at the base of the crown, and the heights of trees were measured, then model trees were cross-cut into logs considering the size and quality of stems, as well as the requirements of standards (Černý \& Pařez 2005). Model tree measurement data were used to parameterize the stem profile equations by which the volumes of model trees and their distribution by assortment were calculated. In total, 234 model trees were measured, and 66 models were cut down and divided into assortments. Inside 12 trees, internal rot was found.

According to new standards for round timber, logs are sorted into four quality classes, namely A, B, C, and D. By the average diameter of logs without bark, industrial timber is divided into ten classes (D0 $<10 \mathrm{~cm}$, D1a 10$14 \mathrm{~cm}, \mathrm{D} 1 \mathrm{~b} 15-19 \mathrm{~cm}, \ldots, \mathrm{D} 10 \geq 60 \mathrm{~cm}$ ) (Hardwood round timber - Qualitative classification 2018).

Class A includes timber of the highest quality, mostly from the bottom of the trunk, without defects or with minor defects. Class B includes middle-class timber with less quality requirements for timber that has restricted knots. Assortments below the middle quality class that allow defects that do not significantly reduce the natural properties of wood are classified as class C. Quality class $\mathrm{D}$ includes timber that does not satisfy any of the higher classes, but from which industrial timber can be obtained.

When evaluating economic types of stand maturity, in particular quantitative and technical the research was based on the growth tables (Kashpor \& Strochynskyi 2013). The age of technical maturity is primarily influenced by the average diameter of the most valuable assortments and wood quality. For determining the age of technical maturity of coppice oak stands, it is also necessary to take into account a decrease in the industrial timber yield due to damage by rot as well as weakening of stands beyond the age of 120 .

The calculations of the marketability dynamics were performed based on the growth tables of modal coppice oak stands and stem distribution models. Following on the above parameters, we calculated the trees distribution by diameter using the STRUK program ( $\beta$-distribution) (Girs et al. 2017).

\section{Results}

According to the analysis of forest stands designated for final felling, the proportion of commercial stems decreases by an average of $25 \%$ and the diameter of rot in the butt-log part increases as the age of stands rises from 110 to 140 . 
The change in the proportion of marketable stems (Pmark) with the stand age (A) was determined from the growth tables of coppice oak stands of the respective site index and data on the distribution of stems by category on temporary sample plots (Fig. 2). Considering the quality deterioration of coppice oak timber aged over 90 years, the percentage of marketable stems in the 80-140 age range was determined by the formula, obtained on the base of data on Fig. 2:

$$
P_{\text {mark }}=-114.9+3.208 \cdot A-0.0147 \cdot A^{2}\left(R^{2}=0.59\right)
$$

According to the calculations, the proportion of marketable stems is the maximum at 110 years, which corresponds to the average diameter of $36 \mathrm{~cm}$ for the forest stands of the II site index class.

The table of commodity structure dynamics for modal oak stands (II site index) according to our data is given below (Table 2).

\section{Discussion}

The quantitative and qualitative wood structure of the studied coppice stands is worse than that of seed stands. Such significant differences are explained by the fact that the oak trees of coppice origin in the study area at an earlier age (110 years) and more frequently affected by rot (Girs et al. 2018). Peculiarities of the structure of the coppice oak stands are factors as well, which should be taken into account in forest management. Tkach (1999) also found a significant reduction in the increment of large industrial timber in coppice oak stands after 90 years of age. We compared the growing stock of large industrial timber graphically (Fig. 3).

The largest values of the yield of large industrial timber were given by Girs (2011) for seed-origin oak stands (Fig. 3). According to our study, stocks of large industrial timber are significantly smaller; this is due to smaller stocks of industrial timber in general and a smaller proportion of large timber in the forests of the study area. Thus, with an average diameter of $24 \mathrm{~cm}$, the proportion of large industrial timber is $13 \%$ according to our data and $26 \%$ according to Girs (2011). Such differences can be explained by the peculiarities of the structure of oak stands in the Left-Bank Forest-Steppe, as well as the fact that Girs' data were obtained for fully stocked high-class seed-origin oak stands.

The age at which the maximum average increment for industrial timber is equal to the current increment is considered to be the age of technical maturity of the stand. The age of technical maturity for A and B classes of industrial timber is 101-110 years for $B$ and $C$ classes of industrial timber is 81-90 years and for industrial timber in total is 91-100 years (Table 3).

In similar conditions of the Russian Federation (forest-steppe of Belgorod and Voronezh Regions), in protective forests, the following ages of final felling were established: 101-120 years for coppice oak stands II and above site indexes, 141-160 years for oak stands of seed origin III and above site indexes (The order of Rosleskhoz 2015).

In Belarus, the lower age limit for final felling for oak stands is set at 101 years (Baginskiy et al. 2019).

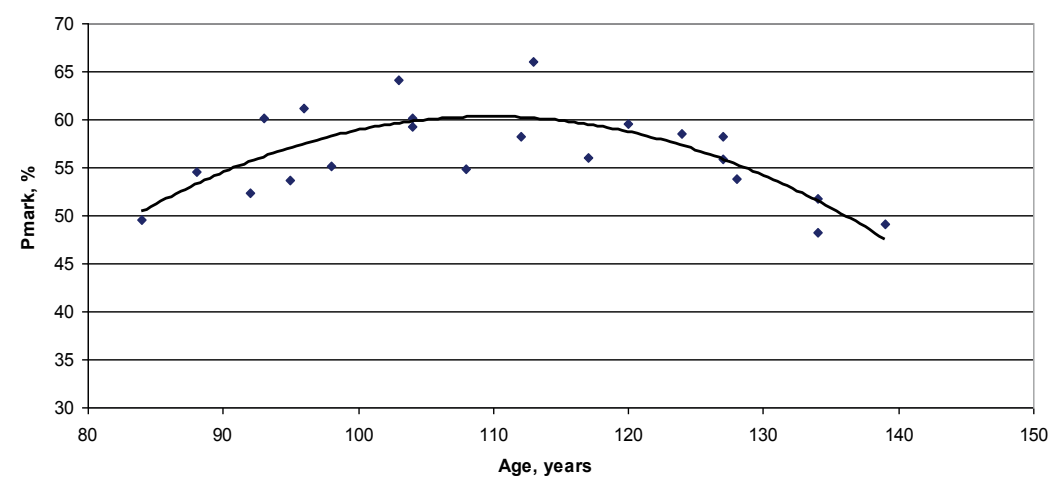

Fig. 2. Proportion of marketable stems in coppice oak stands depending on age.

Table 2. Commodity structure dynamics of modal coppice oak stands.

\begin{tabular}{|c|c|c|c|c|c|c|c|c|c|}
\hline \multirow[b]{2}{*}{ Age [years] } & \multirow[b]{2}{*}{$\mathrm{H}[\mathrm{m}]$} & \multirow[b]{2}{*}{$\mathrm{D}[\mathrm{cm}]$} & \multirow{2}{*}{$\begin{array}{c}\text { Growing stock } \\
{\left[\mathrm{m}^{3} \cdot \mathrm{ha}^{-1}\right]}\end{array}$} & \multicolumn{6}{|c|}{ Distribution of growing stock by size and quality categories $\left[\mathrm{m}^{3} \cdot \mathrm{ha}^{-1}\right]$} \\
\hline & & & & \multicolumn{5}{|c|}{ industrial timber } & fuelwood \\
\hline 70 & 22.6 & 26.9 & 324 & 0 & 30 & 62 & 53 & 145 & 152 \\
\hline 90 & 24.9 & 31.9 & 376 & 19 & 43 & 75 & 61 & 198 & 144 \\
\hline 100 & 25.6 & 33.9 & 394 & 25 & 49 & 79 & 65 & 218 & 140 \\
\hline 110 & 26.2 & 35.5 & 407 & 29 & 52 & 81 & 68 & 230 & 138 \\
\hline 140 & 27.1 & 39.2 & 427 & 32 & 58 & 83 & 73 & 246 & 147 \\
\hline
\end{tabular}




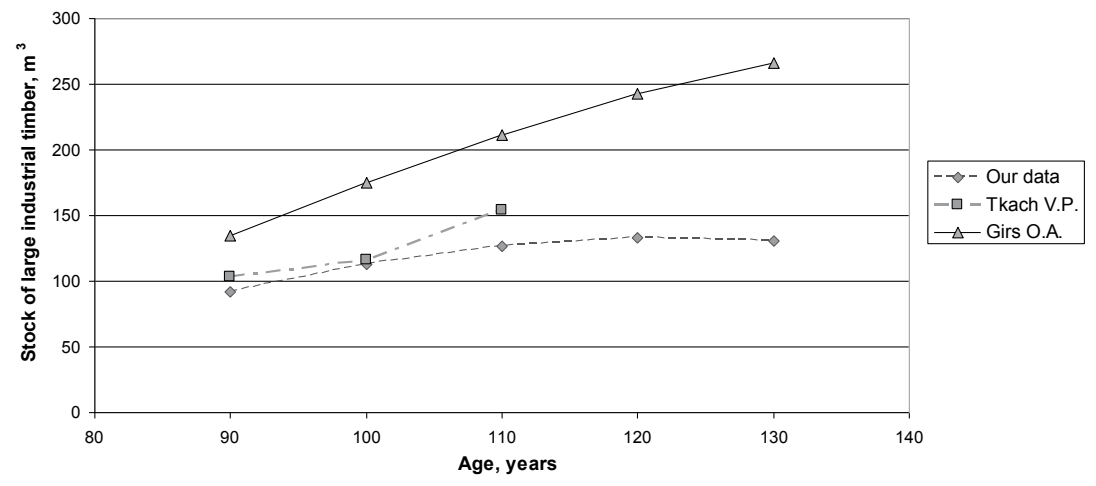

Fig. 3. The growing stock of large industrial timber in oak stands according to different authors (O.A Girs for seed-origin oak stands, V.P. Tkach for floodplain forests).

Table 3. Data for calculation of technical maturity indicators for coppice oak stands of II site index.

\begin{tabular}{|c|c|c|c|c|c|}
\hline \multirow{3}{*}{ Age [years] } & \multirow{3}{*}{$\begin{array}{l}\text { Growing stock } \\
\qquad\left[\mathrm{m}^{3} \mathrm{ha}^{-1}\right]\end{array}$} & \multirow{3}{*}{$\begin{array}{l}\text { Average change in stock } \\
\qquad\left[\mathrm{m}^{3} \mathrm{ha}^{-1}\right]\end{array}$} & \multicolumn{3}{|c|}{ Average change in stock of industrial timbe } \\
\hline & & & \multicolumn{3}{|c|}{$\left[\mathrm{m}^{3} \mathrm{ha}^{-1}\right]$} \\
\hline & & & classes A and B & classes $\mathrm{B}$ and $\mathrm{C}$ & total \\
\hline 70 & 324 & 4.63 & 0.43 & 1.31 & 2.07 \\
\hline 80 & 353 & 4.41 & 0.59 & 1.34 & 2.18 \\
\hline 90 & 376 & 4.18 & 0.69 & 1.31 & 2.20 \\
\hline 100 & 394 & 3.94 & 0.74 & 1.28 & 2.18 \\
\hline 110 & 407 & 3.70 & 0.74 & 1.21 & 2.09 \\
\hline 120 & 418 & 3.48 & 0.73 & 1.15 & 2.00 \\
\hline 130 & 425 & 3.27 & 0.69 & 1.08 & 1.89 \\
\hline
\end{tabular}

Girs et al. (2018), taking into account average increment of industrial timber, proposed to set the age of maturity of 91-100 years for coppice oak stands of II site index for saw logs. Thus, the maturity ages in our study, are close to the data for all coppice oak forests in Ukraine.

Researches from Ukrainian Research Institute of Forestry and Forest Melioration (Torosov et al. 2019) proved the feasibility of applying the projected maturity ages for oak stands by forest categories in the Left-Bank Forest-Steppe (Kharkiv and Chernihiv Regions). Reducing maturity ages (by 1-3 age classes) in coppice oak stands results in an increase of the area of final felling. Further, after 2040, due to the creation of seed oak stands by planting or promoting natural regeneration on-site of former coppice stands the proportion of high-yield oak stands with improved commodity structure will increase (Torosov et al. 2019).

\section{Conclusion}

The commodity structure of oak stands in the Left-Bank Forest-Steppe part of Ukraine has its specificities, which are manifested in smaller stocks of commercial timber as compared to oak stands of Right-Bank Forest-Steppe zone of Ukraine. That is due to the predominance of coppice stands here and inappropriate ages of maturity established earlier. Our investigations show that the maturity age and associated age of final felling for commercial oak forests of coppice origin (II and higher site index) within the Left-Bank Forest-Steppe should be set at 91-100 years ( $\mathrm{X}$ age class).
Setting the optimum maturity ages for oak stands improves the commodity structure of timber produced from logging in rotation period.

We suggest using the proposed tables to evaluate the commodity structure of mature oak coppice stands. Transformation of coppice oak stands into seed stands will improve their productivity and marketability.

\section{Acknowledgment}

The authors thank Oleksandr Borysenko for preparation of the map.

\section{References}

Árvai, M., Morgós, A., Kern, Z., 2018: Growth-climate relations and the enhancement of drought signals in pedunculate oak (Quercus robur L.) tree-ring chronology in Eastern Hungary. IForest-Biogeosciences and Forestry, 11:267-274.

Baginskiy, V. F., Demid, N. P., Lapitskaya, O. V., 2019: New felling ages for the forests of the republic of Belarus. Siberian Journal of Forest Science, 5:30-36.

Bondar, O., Rumiantsev, M., Tkach, L., Obolonyk, I., 2020: Prevailing forest types in the river catchments within the Left-Bank Forest-Steppe zone, Ukraine. Folia Forestalia Polonica, Series A, 62.2:100-113.

Černý, M., Pařez, J., 2005:Zjištování objemu a sortimentace stojících stromů s využitím modelu tvaru kmene. Lesnická práce, 12:22-25.

Davidov, M.V., 1987: The types of growth and estimation of site indexes of stands. Lecture. Kyiv: USHA, 40 p. 
Duncker, P. S., Barreiro, S. M., Hengeveld, G. M., Lind, T., Mason, W. L., Ambrozy, S. et al., 2012: Classification of forest management approaches: a new conceptual framework and its applicability toEuropean forestry. Ecology and Society, 17:51.

Eaton, E., Caudullo, G., Oliveira, S., de Rigo, D., 2016: Quercus robur and Quercus petraea in Europe: distribution, habitat, usage and threats. In: San-MiguelAyanz, J., de Rigo, D., Caudullo, G., Houston Durrant, T., Mauri, A. (eds.): European Atlas of Forest Tree Species, p. 160-163.

Girs, O., 2011: Maturity of forest stands and the use of wood resources in forests of various functional purposes. Korsun'-Shevchenkivs' kyy: Vyd. Maydachenko, $315 \mathrm{p}$.

Girs, O., Lakyda, P., Tkach, V., Pasternak, V., 2018: Methodical recommendations for specifying the age of maturity of the dominant forest-forming species of Ukraine. Kyiv, NULES, 41 p.

Girs, O., Pasternak, V., Slysh, O., 2017: Dynamics of the commodity structure of high-productive oak coppice stands of commercial forests of Ukraine. Scientific Bulletin of NULESU. Series Forestry and Ornamental Horticulture, 278:34-40.

Kashpor, S. M., Strochynskyi, A. A., 2013: Forest inventory handbook. Kiev, Vinichenko, 496 p.

Nicolescu, V. N., Carvalho, J., Hochbichler, E. et al., 2017: Silvicultural Guidelines for European Coppice Forests. Freiburg, $32 \mathrm{p}$.

Ostapenko, B., Tkach, V., 2002. Forest typology. Tutorial. KhSAU named after V.V. Dokuchaev. UkrNDILGA named after G. M. Vysotsky, Kharkiv, 204 p.

Petráš, R., Halaj, J., Mecko, J., 1996: Sortimentačné rastové tabulky drevín, Bratislava, SAP, 252 p.
Praciak, A. et al., 2013: The CABI encyclopedia of forest trees (CABI, Oxfordshire, UK). 536 p.

Shvidenko, A. Z., Buksha, I. F., Krakovska, S. V., 2018: Vulnerability of Ukrainian forests to climate change: monograph. Kyiv, Nika-Centr, 184 p.

Tkach, V. P., Pasternak, V. P., Buksha, I. F., 2002. Ages of maturity in Ukrainian forests and ways of felling system improvement. Forest and Forest Melioration, 101:98-104.

Tkach, V. P., 199: Floodplains forests of Ukraine. Kharkiv, Pravo, 368 p.

Torosov, A. S., Zhezhkun, I. M., Kalashnikov, A. O., Kharchenko, Yu. V., 2019: Economic justification of main felling age for forest stands. Scientific Bulletin of UNFU, 29:82-85.

\section{Other sources}

Climate change guidelines for forest managers. FAO Forestry paper 172 . Rome 2013. 104 p.

Forest Europe 2020. Adaptation to Climate Change in Sustainable Forest Management in Europe, Liaison Unit Bratislava, Zvolen, 2020. 56 p.

Forestry of Ukraine. State Forest Resources Agency of Ukraine. 2017.46 p.

Hardwood round timber - Qualitative classification - Part 1:Oak and beech (EN 1316-1:1997, IDT). DSTU EN 1316-1:2018. Kyiv: URSC, 2018. 16 p.

Nature-based forestry in Central Europe. Alternatives to Industrial Forestry and Strict Preservation. 2006. Edited by Jurij Diaci. Studia forestalia Slovenica. Nr. 126. Ljubljana. 168 p.

The order of Rosleskhoz dated 04.09.2015 N 105 (on 02.07.2015) “On establishing the age of logging” https://rulaws.ru/acts/Prikaz-Rosleshoza-ot 04/09/2015-N-105 